\title{
THE EFFECT OF THERMAL ENVIRONMENT ON DAILY MILK YIELD OF DAIRY COWS
}

\author{
Metodija Trajchev ${ }^{1}$, Dimitar Nakov ${ }^{1}$, Sreten Andonov ${ }^{2}$ \\ ${ }^{1}$ Department of Animal Health and Animal Welfare, Institute of Animal Biotechnology, \\ Faculty of Agricultural Sciences and Food, St. Cyril and Methodius University, \\ Skopje, Republic of Macedonia \\ ${ }^{2}$ Department of Livestock Breeding, Institute of Animal Biotechnology, \\ Faculty of Agricultural Sciences and Food, St. Cyril and Methodius University, \\ Skopje, Republic of Macedonia
}

Received 20 January 2016; Received in revised form 10 May 2016; Accepted 23 May 2016

\begin{abstract}
The primary objective of this research was to evaluate the impact of environmental air temperatures on the milk production of dairy cows. Therefore, the experiment was carried out at the height of summer (from $15^{\text {th }}$ of June to $15^{\text {th }}$ of September) in three small family dairy farms and one commercial dairy farm. In total, 51 dairy cows from the black-white breed were subjected to the study. The season of research was divided into three periods: the period before the hot season, the period of the hot season and the period after the hot season. In each period there were three test days selected that were used for recording the air temperature inside and outside the barns and cow's daily milk yield. Unvaried associations between the test day milk yield of cows and independent environmental and cow factors were done using the linear mixed model for repeated measurements. The statistical model showed that the farm management system and the hot season of the year had significant influence on daily milk yield per cow at the level of $p<0.001$. The test day per periods of the season when milk control was performed and the average test day environmental temperature showed statistically significant influence on daily milk yield per cow at level $\mathrm{p}<0.01$. The present results revealed that environmental air temperatures contributes to considerable loss in the milk production of dairy cows.
\end{abstract}

Key words: dairy cow, environmental heat stress, milk yield

\section{INTRODUCTION}

Over the past decades, improvements in genetic selection for milk production together with good management practices have resulted in increased milk production per cow (1). Historically, genetic selection for increased milk production has resulted in reduced thermal tolerance. Moreover, higher



Copyright: (C) 2016 Trajcev M. This is an open-access article published under the terms of the Creative Commons Attribution License which permits unrestricted use, distribution, and reproduction in any medium, provided the original author and source are credited.

Competing Interests: The authors have declared that no competing interests exist.

Available Online First: 2 June 2016

Published on: 15 October 2016

http://dx.doi.org/10.1515/macvetrev-2016-0084 milk production is increasing the rate of metabolic heat production due to an increased eating and drinking behavior, making the high yielding cows more vulnerable to heat stress than lower yielding ones $(2,3)$. Environmental conditions, such as high air temperature and solar radiation are the main stress factors for dairy cows (4). The etiology of heat stress consists in the failure to maintain core body thermo-neutrality in conditions of increasing ambient temperature and humidity. Exposure of dairy cows to a thermal environment is a major risk factor for decreased milk production, especially in high-yielding cows more than in low-yielding ones $(2,5)$ due to the combined accumulation of heat gained from the environment and metabolic heat. As body temperature rises, the cow enters heat stress. Consequently, in relation to the eating behavior in a hot environment, characterized by lowering feed consumption and increasing water intake as a result of metabolic adaptation to increased body 
temperature, high producing dairy cows in early lactation are more sensitive to heat stress and their milk production declines significantly (6). When dairy cows are under heat stress, the accumulated heat exceeds the body capacity for heat loss by radiation, convection and conduction. In order to reduce the heat load of dairy cows reared under high ambient temperatures accompanied by higher metabolic heat production, additional cooling measures during the year season of thermal stress are required (5). For the purpose of better acclimatization to a hot environment, high producing dairy cattle needs environmental improvements, such as comfort thermal zone inside barns. Dairy cows prefer a socalled "thermo-neutral zone", embracing ambient temperatures between 5 and $25.8^{\circ} \mathrm{C}$, above which the cows expressed physiological disorders and enter heat stress (7).

The manifestations of heat stress in dairy cows depend on the local climatic conditions and the specific management system on the farm. As accurate measurement and quantification of heat stress in a dairy cow is difficult, their occurrence in field studies was related to the ambient temperature surrounding cows, while the quantification was done using milk yields data (8). In practice, the ambient air temperature inside barns is not being recorded ordinarily. With the aim to underline the necessity of thermo-neutral zone for increased milk production of dairy cows reared in different management systems, the primary objective of this research was screening the impact of environmental thermal stress in terms of milk yield losses of dairy cows reared in local conditions in the Republic of Macedonia.

\section{MATERIAL AND METHODS}

The experiment was carried out at the height of the summer (from $15^{\text {th }}$ of June to $15^{\text {th }}$ of September) in three small family dairy farms (farms 1,2 and 3) and one commercial dairy farm (farm 4). The dairy farms are located in the region of Strumica, in the southeastern part of the Republic of Macedonia. The climatic condition in the Republic of Macedonia is Continental - Mediterranean, characterized with very hot and dry periods during the summer. The temperature rises up to $40^{\circ} \mathrm{C}$ during the summer season. In this zone, animals are exposed to a thermal environment for 3-5 months annually.

These farms have a different management system for production (M S). The production management practice in farm 1 and 2 consists of tie-stalls and enclosed barns (M_S_A). The 186 production management practice in farm 3 consists of a tie-stalls enclosed barn, but the cows were let out to graze between the morning and the evening milking (M_S_B). The milking of the cows in farm 1,2 and 3 is performed with a transferable milking system. Furthermore, the production management practice in farm 4 consists of a loose-housing system and open barns (M_S_C). The milking of the cows is performed in a milking parlour. Cows had free access to water in the grazing field and in the rearing pens.

The farms 1, 2 and 3 do not have any cooling system, so the climatic conditions inside the barn are similar to the climatic conditions outside. The farm 4 has a cooling system consisting ofa combination of sprinklers and fans, so this farm was taken for the study as a control. Briefly, the cooling system composed of fans and sprinklers was consecutively activated to repeat cycles of wetting. But, obviously, this capacity for ventilation and cooling satisfied only $50 \%$ of the needed microclimatic conditions.

The cows were milked two times per day (morning and evening milking). However, there was an exception in farm 4, where the cows in the period of early lactation, from calving to the $3^{\text {rd }}$ month of lactation, were milked three times per day (morning, afternoon and evening milking). The test day milk yield per cow was estimated as the sum of the milk yield gained during the daily milking.

Totally 51 dairy cows from the black-white breed were subjects of the study: 12 cows reared in the management system M_S_A, 10 cows reared in the management system M_S_B and 29 cows reared in the management system M_S C .

The season of research was divided into three periods: period before the hot season (season period 1 in year 2015 - S_P_115) beginning from $15^{\text {th }}$ of June to $15^{\text {th }}$ of July, the period of the hot season (season period 2 in year $2015-\mathrm{S}$ P 215) beginning from $16^{\text {th }}$ of July to $15^{\text {th }}$ of August, and period after the hot season (season period 3 in year 2015 - S_P_315), from $16^{\text {th }}$ of August to $15^{\text {th }}$ of September. In each period, three test days were selected. This three test days by period of season (TD_1, TD_2, TD_3) were used for recording the test day milk yield (TDMY) and for measurement of temperatures in three daily points for calculation of the average test day ambient temperature inside barns (TDT IN) and the average test day environmental temperature outside barns (TDT_OUT). Environmental air temperatures for the region of Strumica were obtained from the National Hydrometeorological Service of the Republic of Macedonia. The maximum distance between each farm and meteorological weather station located in that region was around $20 \mathrm{~km}$. 
The average test day ambient temperature (TDT) was estimated using the equation:

$\mathrm{TDT}\left({ }^{\circ} \mathrm{C}\right)$
where:

$\mathrm{T}_{7 \text { am }}=$ air temperature in ${ }^{\circ} \mathrm{C}$ measured in $7 \mathrm{am}$;

$\mathrm{T}_{2 \mathrm{pm}}=$ air temperature in ${ }^{\circ} \mathrm{C}$ measured in $2 \mathrm{pm}$;

$\mathrm{T}_{9 \mathrm{pm}}=$ air temperature in ${ }^{\circ} \mathrm{C}$ measured in $9 \mathrm{pm}$.

The dairy cows in farm 1,2 and 4 were fed with a mixed ratio of roughage/concentrate. The amount of the roughage/concentrate ration of diet was based on individual cow's requirements, calculating individual milk production. The dairy cows in farm 3 were fed with grazed roughage ad libitum. Water was available at all times throughout the experiment, so the watering of animals was ad libitum.

The ration was modified during the trial according to the scores of the milk production and the body condition of the cows.

Univaried associations between the test day milk yield of cows and independent environmental and cow factors was done using a linear mixed model for repeated measurements. The model includes the individual cow as the random effect. Following regression analysis, the significant differences in mean values for test day milk yield between groups were estimated by the Bonferoni significant difference test.

The model was:

$\mathrm{Y}_{\mathrm{ijklm}}=\mu+\mathrm{F}_{-} \mathrm{M}_{\mathrm{i}}+\mathrm{S}_{-} \mathrm{P}_{\mathrm{j}}+\mathrm{TD}_{\mathrm{k}}+\mathrm{b}_{1}\left(\mathrm{TDT}_{-}\right.$ IN) $+c_{m}\left(\right.$ TDT_OUT) $+\mathrm{e}_{\mathrm{ijklm}}$ where:

$Y_{\mathrm{ijklmn}}=$ the dependent variable; $\mu=$ overall mean, $\mathrm{F}_{-} \mathrm{M}_{\mathrm{i}}=$ fixed effect of farm management $(\mathrm{I}=1,2$, 3); $\mathrm{S}_{-} \mathrm{P}_{\mathrm{j}}=$ fixed effect of periods before, during and after the hot season $(j=1,2,3) ; \mathrm{TD}_{\mathrm{k}}=$ test day per periods of season when milk control was performed $(\mathrm{k}=1,2,3) ; \mathrm{b}_{1}($ TDT_IN $)=$ regression coefficient for covariance of measured average test day ambient temperature inside barns; $\mathrm{c}_{\mathrm{m}}$ (TDT_OUT) $=$ regression coefficient for covariance of measured average test day environmental temperature; $\mathrm{e}_{\mathrm{ijk} k \mathrm{mn}}=$ random error.

\section{RESULTS}

Variations of the test day air temperatures inside the barns and test day air temperatures in the environment outside the barns during the trial, related to the periods before, during and after hot season are shown in Figure 1.

The period of the hot season was characterized with higher ambient temperatures inside the barns which ranged from $28.50{ }^{\circ} \mathrm{C}$ to $32.50{ }^{\circ} \mathrm{C}$ compared with the periods before and after the hot season. Also, the environmental air temperatures in the period of the hot season were higher, ranging from $28.50{ }^{\circ} \mathrm{C}$ to $30.60{ }^{\circ} \mathrm{C}$. The period after the hot season was characterized with significantly lower air temperatures compared to the previous periods.

Variations of test day milk yield per cow depending on the management system and periods related to the hot season of year, are shown on Figure 2.

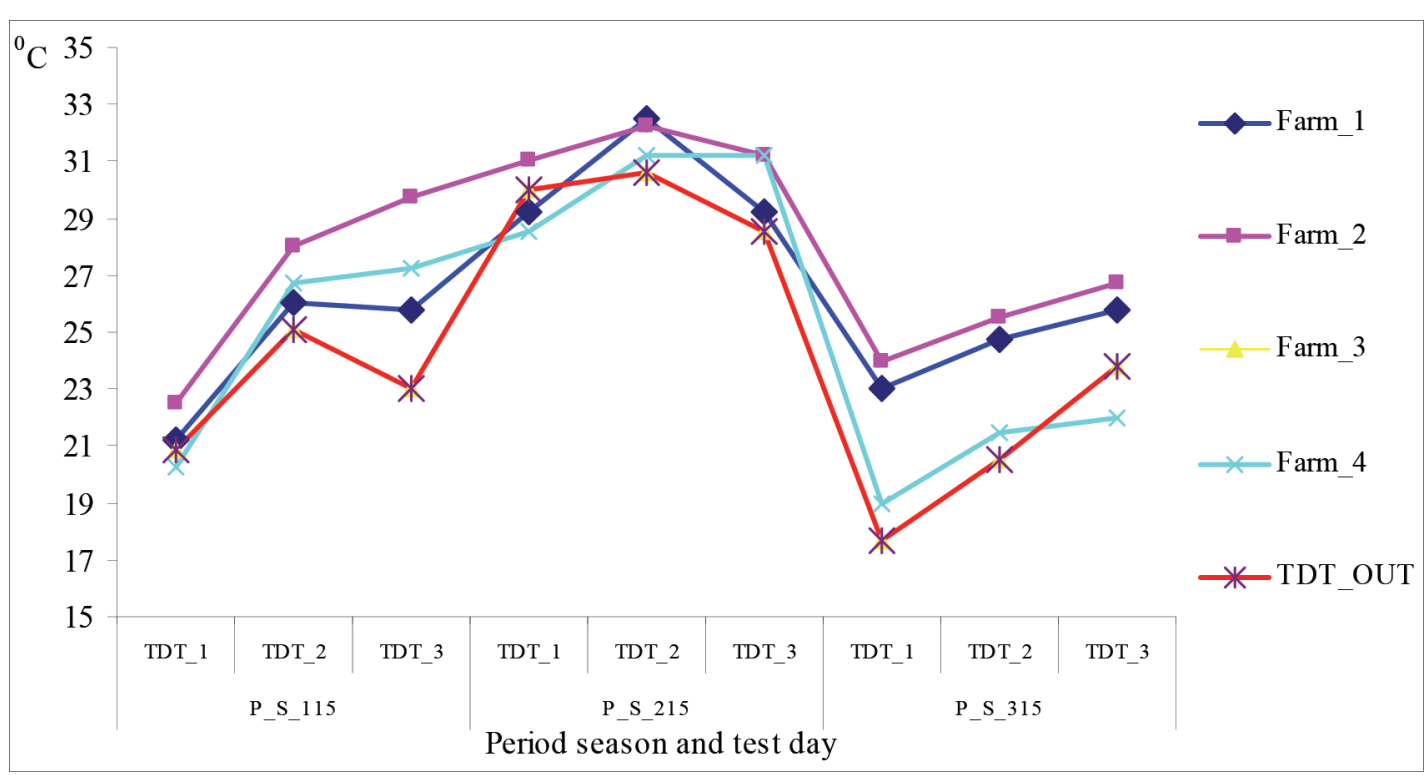

Figure 1. Variations of test day ambient temperatures during the study period 


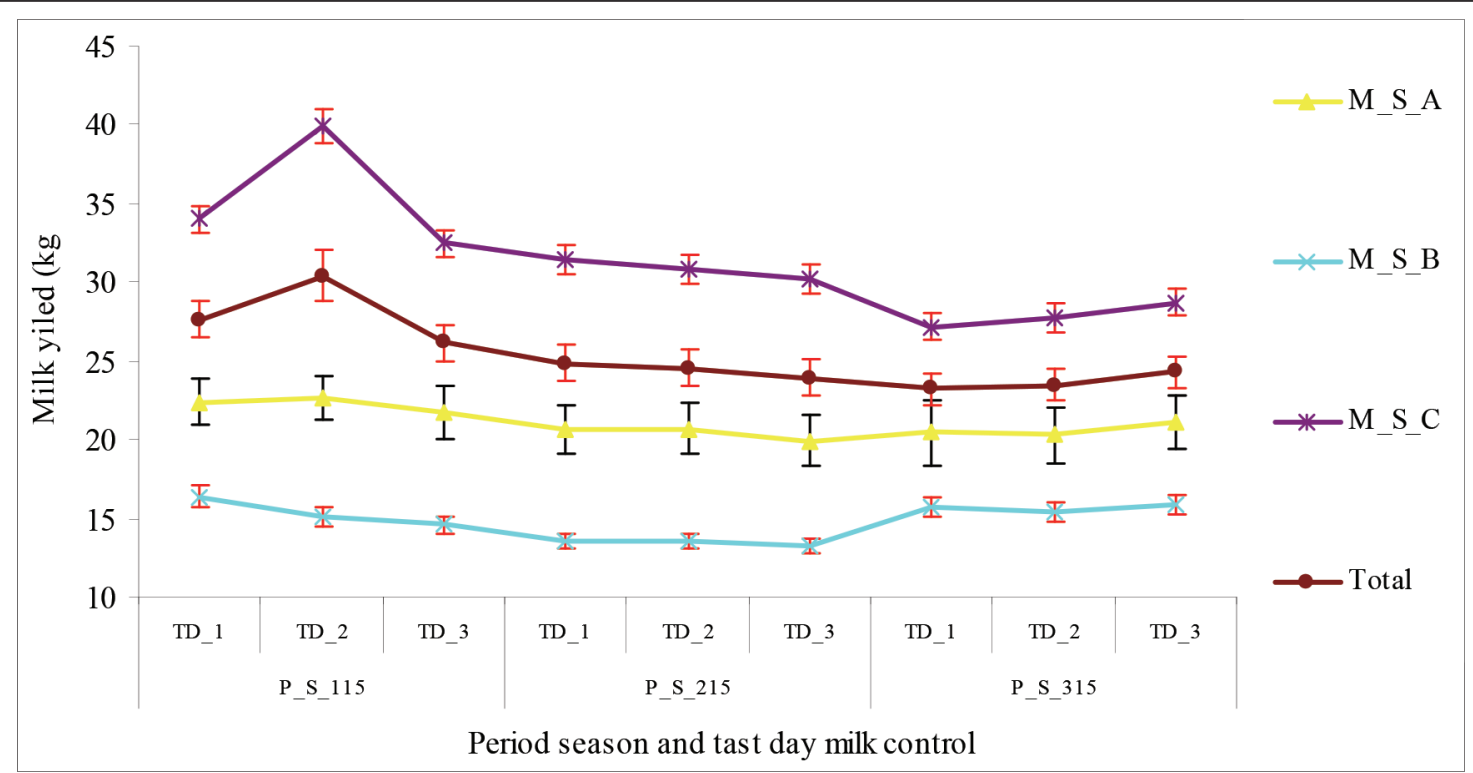

Figure 2. Variations of the daily milk yields per cow depending on the periods during the season

Generally, during the trial period, the highest daily milk yield per cow was recorded for the cow population reared in the management system M_S_C and the lowest ones were recorded for the cow population in management system M_S_B. The average daily milk yield per cow recorded for the population reared in the management system M_S_A were somewhere between the data recorded in $\mathrm{M} S \mathrm{~B}$ and M S C. It was obvious that the recorded values for the daily milk yields per cow in all of the management systems during the period of the hot season were lower than values recorded in the previous period.

In the period after the hot season, the data for daily milk yield per cow for the population in M_S_A and M_S_C showed a trend of continuous decrease, like in the period of the hot season with an exception for the cow population in the M_S B. The values for the daily milk yields per cow in M_S_B were similar with the values obtained in the period before heat stress. Thus, the lowest mean values for the daily milk yields per cow were recorded in the period after the hot season of the year.

In Table 1, the results are shown from the statistical model used for the determination the influence of fixed environmental and cow factors on daily milk yield per cow.

The statistical model showed that there was a significant influence at a level of $p<0.001$ for farm management systems and periods before, during and after the hot season. The test day per periods when milk control was performed and the average

Table 1. The influence of environmental variable and cow factors on daily milk yields

\begin{tabular}{lccc}
\hline \multicolumn{2}{l}{ Dependent variable: test day milk yield per cow (TDMY) } & & \\
\hline Source of variations & df & Mean square & F-value \\
\hline Model & 9 & 36078.564 & $1514.978^{* * *}$ \\
M_S & 2 & 10743.482 & $451.131^{* * *}$ \\
S_P & 2 & 1169.186 & $49.095^{* * *}$ \\
TD & 2 & 92.205 & $3.872^{* *}$ \\
TDT_IN & 1 & 6.368 & $0.268^{\mathrm{NS}}$ \\
TDT_OUT & 1 & 164.321 & $6.900^{* *}$ \\
error & 449 & 23.815 & \\
Total & 458 & & \\
\hline $\mathbf{R}^{2}=\mathbf{0 . 9 6 7}$ & & \\
\hline & $* * *$ significant at the $\mathrm{p}<0.001$ level & & \\
$\quad * *$ significant at the $\mathrm{p}<0.01$ level & &
\end{tabular}


The effect of thermal environment on daily milk yield of dairy cows

test day environmental air temperature outside barns showed statistical significant influence on daily milk yield per cow at a level $\mathrm{p}<0.01$.

There were statistically significant differences in mean values for daily milk yield of cows reared in different management systems (Table 2). in dairy cows. Therefore, high producing dairy cows need comfort thermal zone inside barns. Due to climate changes, the cattle are more often exposed to environmental thermal stress compromising their ability to adequately regulate internal body temperature and maintain all physiological and

Table 2. Bonferoni test for difference in mean values for daily milk yield of cows reared in three different management systems

\begin{tabular}{ccc}
\hline M_S & M_S_B & M_S_C \\
\hline M_S_A & $6.494^{*}$ & $8.323^{*}$ \\
M_S_B & & $14.817^{*}$ \\
\hline
\end{tabular}

*significant at level $\mathrm{p}<0.05$

Concerning the hot seasons when cows were exposed to environmental thermal stress, there were statistically significant differences in the mean value for daily milk yield of cows in the period before thehot season compared to the periods during and after the hot season (Table 3). immunological functions (9). One of the greatest challenges concerning dairy farmers is effective dairy cow management and milk production in the hot season.

The thermal environment is a major risk factor for declining of milk production, especially for

Table 3. Bonferoni test for difference in mean values for daily milk yield of cows in different season periods before, during and after environmental heat stress

\begin{tabular}{ccc}
\hline S_P & S_P_215 & S_P_315 \\
\hline S_P_115 & $7.239^{*}$ & $3.814^{*}$ \\
S_P_215 & & 3.425 \\
\hline
\end{tabular}

*significant at level $\mathrm{p}<0.05$

The Bonferoni test showed a statistically significant difference in daily milk yield per cow measured in the first and the second test day compared to the milk yield measured in the third test day (Table 4). dairy cows of high genetic merit. Quantifying direct environmental effects on milk production is difficult because milk production has a multifactorial determination by several factors, such as nutritional management and other genetic and paragenetic factors

Table 4. Bonferoni test for difference in mean values for daily milk yield of cows in different test days

\begin{tabular}{ccc}
\hline TD & TD_2 & TD_3 \\
\hline TD_1 & 0.472 & $1.829^{*}$ \\
TD_2 & & $1.357^{*}$ \\
\hline
\end{tabular}

*significant at level $\mathrm{p}<0.05$

\section{DISCUSSION}

The Republic of Macedonia belongs to the Mediterranean climatic zone, characterized with very hot and dry periods during summer with an air temperature peak around $45^{\circ} \mathrm{C}$. Annual exposition of animals to environmental heat stress lastsfor 3-5 months. Apart from the climatic conditions, the microclimatic conditions inside the barns and their management also influences heat stress occurrence
An abundance of research has been conducted to alleviate the negative effect of heat stress on milk production, whereupon the main question was the determination of lower temperature when dairy cows currently start experiencing heat stress considering their physiological and productive status. In most studies the temperature-humidity index is used as an indicator of heat stress (10). Using only air temperature data as an indicator for heat stress gives an opportunity for replacing the 
data from meteorological stations with the on-farm level data, whereas milk losses can be estimated by calculations based on the duration of the hot season.

The negative effect of thermal environmental stress occurs when the average daily air temperature is higher than the upper critical temperature for milk production ranging from 16 to $20^{\circ} \mathrm{C}(8)$. However, the maximum critical temperature can vary due to the physiological status of cow in correlation with environmental factors.

Some literature data reported the positive correlation between high environmental temperatures and decreased milk production (11). The results from the trial clearly indicate that heat stress significantly decreases milk production in dairy cows. The decrease in milk production of heat stressed cows was expected and consistent with previous reports (12). According to Silanikove et al. (13), exposure to environmental thermal stress induced a fast reduction in milk yield within 24 hours. The higher yielding dairy cows are more sensitive to the thermal environment and heat stress than the lower-yielding herdmates. Coppock et al. (14) concluded that high-yielding dairy cows are more affected because of lower thermo-neutral zone shifts then milk production, feed intake, and metabolic rate increase. Consequently, homeostatic thermoregulatory mechanism delivered by lower feed consumption and increased water intake is the direct reason for decreased milk production (15).

Even though the physiological mechanisms are unclear, it is believed that these metabolic modifications under heat stress during lactation account for approximately $50 \%$ of the milk production loss observed (6), whereas decreased dry matter intake (DMI) explains the remainder of the depressed milk yield (16). Also, it was found that the stage of lactation has a negative influence on milk production under the environmental condition of heat stress (17).

Environmental heat stress has a long lasting effect on milk productivity of dairy cows and the losses were greater in higher yielding cows. If we take into consideration the whole trial period, then the losses of milk yield during the period of environmental heat stress were even higher and the cows recovered slowly from heat stress. Therefore, higher yielding dairy cows need a longer period of acclimatization to reach milk production on a level similar to the one before the heat stress. Settivary et al. (18) indicate that negative effect of heat stress on milk production is delayed up to 4 days after the end of an induced thermal stress. Heat stress compromises lactational performance not only 190 when occurring during lactation (5), but also during the nonlactating period before parturition.

During the trial, the environmental air temperature very often was lower than the air temperature measured inside the barns. Therefore, the ambient temperature inside the barns in the height of the day was above the critical temperature, even when the average air temperature outside the barn was under the critical value. This indicates that the cows should be kept inside the barns during the hot season at least if the barns are adequately cooled. Heat environmental stress can be moderated by numerous management techniques. Previous reports showed that grazing dairy cows have been harmfully affected by direct solar radiation and high environmental temperatures, and the upper critical temperature for peak lactating dairy cows is considered to be as low as $25^{\circ} \mathrm{C}$ (19). The impact of heat stress on grazing dairy cows has been alleviated by using shades, which have beneficial effects on feed intake, milk yield and metabolic homeostasis (20). Other cooling procedures used on dairy farms included systems of sprinklers and fans.

Generally, feeding modifications, environmental conditioning and genetic selection for heat tolerance remain the 3 best strategies to avoid the negative effects of heat stress on dairy cattle (1). The present findings of the compromised milk production of dairy cows during thermal environmental stress may stimulate agricultural engineers and farmers to improve internal barn designs as a method for effective control of ambient condition for providing comfort thermal zone for dairy cows during hot environments. This will increase milk production and farm profitability in hot seasons. Higher heat production inside barns requires additional measures for cooling a cow during periods of environmental thermal stress (4). Keister et al. (21) and Valtorta and Gallardo (22) reported that the milk yield was significantly improved by the installation of cooling systems in the holding pen.

\section{CONCLUSION}

The environmental heat stress contributes toconsiderable loss in the milk production of the dairy cows. The farm management system and high environmental temperatures during the hot season had statistically significant influence on daily milk yield. The results from this trial can be a good basis for future quantification of the physiological effects of climatic changes on high-producing cows. 
The effect of thermal environment on daily milk yield of dairy cows

\section{ACKNOWLEDGEMENT}

The findings presented in this paper are part of the USAID Adaptation to Climate Change in Agriculture project activities implemented by the Rural Development Network of the Republic of Macedonia.

\section{REFERENCES}

1. Renaudeau, D., Collin, A., Yahav, S., de Basilio, V., Gourdine, J. L., Collier, R. J. (2012). Adaptation to hot climate and strategies to alleviate heat stress in livestock production. Animal 6, 707-728. http://dx.doi.org/10.1017/S1751731111002448 PMid:22558920

2. Kadzere, C.T., Murphy, M.R., Silanikove, N., Maltz, E. (2002). Heat stress in lactating dairy cows: a review. Livest Prod Sci. 77, 59-91. http://dx.doi.org/10.1016/S0301-6226(01)00330-X

3. Wheelock, J.B., Rhoads, R.P., Van Baale, M.J., Sanders, S.R., Baumgard, L.H. (2010). Effects of heat stress on energetic metabolism in lactating Holstein cows. J. Dairy Sci. 93, 644-655.

http://dx.doi.org/10.3168/jds.2009-2295

PMid:20105536

4. Silanikove, N. (2000). Effects of heat stress on the welfare of extensively managed domestic ruminants. Livest Prod Sci. 67, 1-18. http://dx.doi.org/10.1016/S0301-6226(00)00162-7

5. Collier, R.J., Dahl, G.E., Van Baale, M.J. (2006). Major advances associated with environmental effects on dairy cattle. J Dairy Sci. 89, 1244-1253. http://dx.doi.org/10.3168/jds.S0022-0302(06)72193-2

6. Rhoads, M.L., Rhoads, R.P., Van Baale, M.J., Collier, R.J., Sanders, S.R., Weber, W.J., Crooker, B.A., Baumgard, L.H. (2009). Effects of heat stress and plane of nutrition on lactating Holstein cows: I. Production, metabolism, and aspects of circulating somatotropin. J. Dairy Sci. 92,1986-1997.

http://dx.doi.org/10.3168/jds.2008-1641 PMid:19389956

7. Roenfeldt, S. (1998). You can't afford to ignore heat stress. Dairy Manage 35 (5): 6-12.

8. Andre, G., Engel, B., Berentsen, P.B.M., Vellinga, Th.V., Oude Lansink, A.G.J.M. (2011). Quantifying the effect of heat stress on daily milk yield and monitoring dynamic changes using an adaptive dynamic model. J. Dairy Sci. 94, 4502-4513. http://dx.doi.org/10.3168/jds.2010-4139

PMid:21854922

9. Meehl, G.A., Stocker, T.F., Collins, W.D., Friedlingstein, P., Gaye, A.T., Gregory, J.M., Kitoh, A., Knutti, R., Murphy, J.M., Noda, A., et al. (2007). Climate change 2007: the physical science basis. Cambridge: Cambridge University Press.
10. Bohmanova, J., Misztal, I., Cole. J.B. (2007). Temperature-humidity indices as indicators of milk production losses due to heat stress. J. Dairy Sci. 90,1947-1956.

http://dx.doi.org/10.3168/jds.2006-513

PMid:17369235

11. Gantner, V., Mijic, P., Kuterovac, K., Solic, D., Gantner, R. (2011). Temperature-humidity index values and their significance on the daily production of dairy cattle. Mljekarstvo 61, 56-63.

12. Wolfenson, D., Flamenbaum, I., Berman, A. (1988). Dry period heat stress relief effects on prepartum progesterone, calf birth weight, and milk production. J. Dairy Sci. 71, 809-818. http://dx.doi.org/10.3168/jds.S0022-0302(88)79621-6

13. Silanikove, N., Fira Shapiro, F., Shinder, D. (2009). Acute heat stress brings down milk secretion in dairy cows by up-regulating the activity of the milkborne negative feedback regulatory system. BMC Physiology, 9, 13.

http://dx.doi.org/10.1186/1472-6793-9-13

PMid:19563620 PMCid:PMC2714494

14. Coppock, C.E., Grant, P.A., Portzer, S.J., Charles, D.A., Escobosa, A. (1982). Lactating dairy cow responses to dietary sodium, chloride, and bicarbonate during hot weather. J. Dairy Sci. 65, 566-576. http://dx.doi.org/10.3168/jds.S0022-0302(82)82234-0

15. Tapki, I., Ahmet Sahin, A. (2006). Comparison of the thermoregulatory behaviors of low and high producing dairy cows in a hot environment. Appl. Anim. Behav. Sci. 99, 1-11. http://dx.doi.org/10.1016/j.applanim.2005.10.003

16. Gorniaka, T., Meyera, U., Südekumb, K.H., Dänickea, S. (2014). Impact of mild heat stress on dry matter intake, milk yield and milk composition in mid-lactation Holstein dairy cows in a temperate climate. Arch Anim Nutr. 68(5): 358-369. http://dx.doi.org/10.1080/1745039X.2014.950451 PMid:25176045

17. Johnson, H.D. (1987). Bioclimate effects on growth, reproduction and milk production. In: Johnson, H.D. (Ed.), Bioclimatology and the adaptation of livestock (pp. 35-57). Elsevier, Amsterdam.

18. Settivari, R.S., Spain, J.N., Ellersieck, M.R., Byatt, J.C., Collier, R.J., Spiers. D.E. (2007). Relationship of thermal status to productivity in heat stressed dairy cows given recombinant bovine somatotropin. J. Dairy Sci. 90, 1265-1280. http://dx.doi.org/10.3168/jds.S0022-0302(07)71615-6

19. Hemsworth, P.H., Barnett, J.L., Beveridge, L., Matthews, L.R. (1995). The welfare of extensively managed dairy cattle: a review. Appl. Anim. Behav. Sci. 42, 161-182. http://dx.doi.org/10.1016/0168-1591(94)00538-P 
20. Roman-Ponce, H., Thatcher, W.W., Wilcox, C.J. (1981). Hormonal interrelationships and physiological responses of lactating dairy cows to a shade management system in a subtropical environment. Theriogenology 16, 139-154.

http://dx.doi.org/10.1016/0093-691X(81)90097-2

21. Keister, Z.O., Moss, K.D., Zhang, H.M., Teegerstrom, T., Edling, R.A., Collier, R.J., Ax, R.L. (2002). Physiological responses in thermal stressed Jersey cows subjected to different management strategies. J. Dairy Sci. 85, 3217-3224.

http://dx.doi.org/10.3168/jds.S0022-0302(02)74410-X
22. Valtorta, S.E., Gallardo, M.R. (2003). Evaporative cooling for Holstein dairy cows under grazing conditions. Int J Biometeorol. 48, 196.

Please cite this article as: Trajchev M., Nakov D., Andonov S. The effect of thermal environment on daily milk yield of dairy cows. Mac Vet Rev 2016; 39 (2): 185-192. http://dx.doi.org/10.1515/macvetrev-2016-0084 